\title{
Water and fertilization management of vegetables: state of art and future challenges
}

\author{
S. De Pascale ${ }^{1}$, Y. Rouphael ${ }^{1}$, M. Gallardo ${ }^{2}$ and R.B. Thompson ${ }^{2}$ \\ ${ }^{1}$ Department of Agricultural Sciences, University of Naples Federico II, Portici, Naples, Italy \\ ${ }^{2}$ Department of Agronomy, CIAMBITAL Research Centre for Mediterranean Intensive Agrosystems and Agrifood \\ Biotechnology, ceiA3 Agrifood Campus of International Excellence, University of Almeria, Almeria, Spain
}

\section{Summary}

In the coming few years, one of the major challenges for the vegetable industry will be to ensure sufficient production for the increasing world population in a sustainable way, with improved water and nutrient use efficiency. Therefore, vegetable growers and extension specialists should shift from maximizing yield per unit of production area to maximizing productivity per unit of water and/or nutrient used. The present work provides an updated overview of recent scientific studies regarding tools and techniques to determine the amounts and timing of irrigation and of nitrogen fertilizer. Optimizing $\mathrm{N}$ fertilization through soil testing approaches, soil solution analyses, $\mathrm{N}$ balance calculations, decision support systems, and using plant and crop monitoring approaches are considered. Best management practices are discussed including the application of plant biostimulants, and the use of vegetable grafting. The review concludes by identifying the most promising research lines for improving water and nutrient use efficiency in vegetable crop production.

Keywords

decision support system, fertilization, nutrient use efficiency, plant biostimulants, soil moisture sensors, sustainable horticulture, water use efficiency

\section{Introduction}

Over the past twenty years, food security has become a pivotal concern for developing and undeveloped areas of the world, which is magnified by global population increase and the severe effects of climate change on horticulture. Vegetable crops represent an essential part of the human diet because of their high nutritional value and their content of bioactive compounds (Slavin and Lloyd, 2012; Kyriacou and Rouphael, 2018). They have a role to play for enhancing food security, especially when considering highly intensified cropping systems such as protected cultivation (Rouphael et al., 2018a, b). Open field vegetable production and especially greenhouse vegetable industry apply more fertilizer and water per unit of production area compared to other cropping systems (Colla et al., 2015a; Rouphael et al., 2016a). A primary challenge for extension specialists, growers and scientists associated with the vegetable industry is to ensure high yield and product quality using sustainable management with improved efficiency in the use of water and nutrients (Colla et al., 2017a, b; Rouphael et al., 2017a).

\section{Significance of this study}

What is already known on this subject?

- Open field vegetable production, and especially greenhouse vegetable industry, apply more fertilizer and water per unit of production area compared to other cropping systems. A primary challenge for the vegetable industry will be to ensure high crop productivity using sustainable management with improved efficiency in the use of water and nutrients.

What are the new findings?

- This review will offer a comprehensive synthesis of information on the use of plant biostimulants, vegetable grafting, models, DSSs, sensors and other forms of monitoring soil and plants, and soil analysis to improve the use of nitrogen and irrigation.

What is the expected impact on horticulture?

- The overall impact of this review could be of interest for all actors (scientists, extension specialists and growers) dealing with the vegetable sectors by identifying recent scientific studies regarding tools and techniques to determine the amounts and timing of irrigation and of nitrogen fertilizer, and consequently increasing water and nutrient use efficiency.

The application of chemical fertilizers, in particular nitrogen $(\mathrm{N})$, has often been associated with an increase in environmental pollution due to the limited crop uptake of applied nutrients (e.g., often $30-40 \%$ of applied N) by fast growing crop species such as vegetables (Glass, 2003; Colla et al., 2015a). Therefore, there is an urgent need among scientists, extension specialists and growers to accurately quantify the nutrient requirements of vegetable crops in order to maximize the production while limiting losses of $\mathrm{N}$ and phosphorus (P) which are associated with nitrate $\left(\mathrm{NO}_{3}{ }^{-}\right)$contamination of aquifers and eutrophication of surface waters (De Pascale et al., 2017). Several novel approaches to optimize $\mathrm{N}$ fertilizer use such as soil and plant nutrient testing, irrigation methods (subsurface drip irrigation) as well as simplified decision support systems (DSSs) have been shown to be effective tools to improve Nitrogen Use Efficiency (NUE, harvested yield per unit of nutrient used) in vegetable crop production (Thompson et al., 2015, 2017a, b; De Pascale et al., 2017).

Another important issue in vegetable cropping systems is to maximize productivity per unit of water use, in other 
words maximizing Water Use Efficiency (WUE, harvested yield per unit of water used) (Rouphael and Colla, 2005; De Pascale et al., 2011). This can be accomplished through water management practices that reduce water losses (drainage, runoff) and also by an appropriate choice of high-yielding cultivars and/or suitable grafting combinations (Colla et al., 2008; De Pascale et al., 2011). Major improvements in WUE can be obtained through innovative tools and techniques that determine the amounts and timing of irrigation (Gallardo et al., 2013; Thompson et al., 2015). The adoption of methods i) to control soil moisture (soil moisture sensors); ii) to evaluate crop water status (Infrared thermometry for leaf temperature); and iii) calculation of water balance and crop evapotranspiration through simplified models, have been reported to reduce the amount of water applied to the cropping system by up to $50 \%$ (Tognoni et al., 2002).

Accordingly, the present review aims to provide an updated overview of scientific studies addressing innovative tools and techniques to accurately determine the amounts and timing of irrigation and to optimize $\mathrm{N}$ fertilization of vegetable crops. Moreover, in the same context, innovative crop management practices are discussed, including grafting and application of natural plant biostimulants. The review concludes by identifying several approaches and research areas that may be adopted to optimize water and $\mathrm{N}$ fertilization.

\section{Irrigation management strategies}

\section{Tools and techniques to accurately determine the amounts and timing of irrigation}

To assist in determining the timing and volumes of irrigation of vegetable crops, two general approaches are used, (a) the water balance method based on estimation of crop evapotranspiration $\left(\mathrm{ET}_{\mathrm{c}}\right)$, and (b) soil moisture sensors. The use of measurements of plant water status for irrigation scheduling has been investigated (e.g., Gallardo et al., $2006 \mathrm{a}, \mathrm{b}$ ) but there has been little implementation with commercial vegetable crops (E. Berkmoes, unpublished survey data, FERTINNOWA project, http://www.fertinnowa.com/ project/).

\section{Water balance and crop evapotranspiration (ET)}

The water balance is a classical and well-established method for irrigation scheduling (IS). It is easy to use and affordable. However, its use involves some uncertainty because it is usually based on the estimation, rather than measurement, of various components. This method consists of the estimation of the decrease in soil water content (SWC) of the root zone, for periods of time (e.g., daily), as the difference between inputs (effective rainfall and irrigation) and outputs of water (crop evapotranspiration $\left(\mathrm{ET}_{\mathrm{c}}\right.$ ), and drainage and runoff where they occur). The objective is to maintain the SWC in the root zone within a range of SWC that is optimal for the crop, thereby avoiding crop water stress, where the physiology of the crop is negatively affected by an insufficient supply of water. As SWC decreases through $\mathrm{ET}_{\mathrm{c}}$ to a threshold value, irrigation is then required with a volume that restores the SWC to field capacity. Allen et al. (1998) provide a detailed description of this method. When using high-frequency irrigation systems (i.e., drip), which is common in vegetable crops, the SWC is maintained close to field capacity and the volume of irrigation is equal to $\mathrm{ET}_{\mathrm{c}}$ minus rainfall since the previous irrigation. In this case, the water balance method only determines the volume of irrigation and a soil sensor is required to determine the irrigation frequency. The irrigation volumes, estimated by the water balance calculation, should be increased to consider application efficiency (i.e., the proportion of applied water that remains in the crop root zone) and the salinity of the irrigation water when it is sufficiently high that additional irrigation is required to leach salts from the root zone (Rhoades and Loveday, 1990; Gallardo et al., 2013). In order to use the water balanced method, it is very important to have a good estimate of $\mathrm{ET}_{\mathrm{c}^{*}}$. Approaches to estimate $\mathrm{ET}_{\mathrm{c}}$ for irrigation scheduling of vegetable crops have been reviewed by Pardossi and Incrocci (2011), Gallardo et al. (2013) and Cahn and Johnson (2017).

Following the approach developed by the Food and Agricultural Organisation (FAO), $\mathrm{ET}_{\mathrm{c}}$ is estimated from (a) reference evapotranspiration $\left(\mathrm{ET}_{0}\right)$ values derived from local climatic data, and (b) locally-derived or general crop coefficient $\left(K_{c}\right)$ values (Allen et al., 1998). Reference evapotranspiration is estimated using generic FAO recommended equations (e.g., Penman Monteith; Allen et al., 1998) or local adaptations of these equations (Gallardo et al., 2013). To find the required input data for estimation of $\mathrm{ET}_{0}$, networks of public weather stations (e.g., CIMIS in California, FAWN in Florida, Estaciones Agroclimaticas, Junta de Andalucía in Spain) or affordable weather stations located in the farms are options.

The standard FAO method of calculating $\mathrm{ET}_{\mathrm{c}}$ using three constant $\mathrm{K}_{\mathrm{c}}$ values, each for a fixed length crop stage (Allen et al., 1998), is not well suited for vegetable crops. With vegetable crops, planting dates and lengths of crop cycles can vary appreciably in response to market prices, weather conditions, and farm management considerations (Gallardo et al., 2013). Because of this variability and considering that crop coefficients are well related to crop growth, i.e., degree of crop canopy cover (Grattan et al., 1998), mathematical models can be used to estimate daily $\mathrm{K}_{\mathrm{c}}$ values (Gallardo et al., 2013), for example as a function of growing degree days. Orgaz et al. (2005) used models to calculate $K_{c}$ values for greenhouse vegetable crops. Gallardo et al. (1996) developed a $\mathrm{K}_{c}$ model for lettuce that was based on ground cover.

In vegetable crops that have a slow rate of growth during the initial part of the season, such as lettuce, the calculation of $\mathrm{K}_{\mathrm{c}}$ is complex and depends mainly on factors that determine soil evaporation, such method and frequency of irrigation, and the soil type. Where evaporation is an appreciable component of $\mathrm{ET}_{\mathrm{c}}$, it is recommended to use models that separately calculate evaporation from the soil surface (E), and transpiration (T) from the crop (Gallardo et al., 1996). For lettuce, Gallardo et al. (1996) developed a dual model which separately calculated $\mathrm{E}$ and $\mathrm{T}$, which is consistent with the approach of Allen et al. (1998). In a recent review, Cahn and Johnson (2017) described these models in detail.

Given the mathematical complexity involved in the calculation of $\mathrm{ET}_{\mathrm{c}}$ which involves the use of models to calculate both $\mathrm{ET}_{0}$ and $\mathrm{K}_{\mathrm{c}}$, spreadsheets and software have been developed for irrigation scheduling, e.g., CROPWAT (Smith, 1992). Many of these products are available for field crops, but few of these products are suitable for vegetable crops. Also, in many cases (e.g., CROPWAT) users have to manually retrieve the climatic data required for $\mathrm{ET}_{0}$ calculation, which discourages the use of these tools in commercial farms. Currently there is a new generation of web-based irrigation software for field crops that have automatic retrieval of weather data through web browsers operated with smartphones, tablets or computers, e.g., SmartIrrigation (Migliaccio et al., 2016), IrriSatSMS (Car et al., 2012), IRRINET (Mannini et al., 2013). The web-based software CropManage (Cahn et al., 2014) has been developed specifically for cool-season vegetables 
in the Central Coast region of California, using a dual crop coefficient approach. More information about recent developments in software for irrigation scheduling in vegetables can be found in the reviews by Cahn and Johnson (2017) and Thompson et al. (2017b).

The software PrHo V2.0 (Fernández et al., 2009) was developed for irrigation scheduling of soil-grown greenhouse vegetable crops in Almeria, Spain based on the general FAO method and using a single $\mathrm{K}_{\mathrm{c}}$ approach. Using PrHo, historical $\mathrm{ET}_{0}$ can be calculated from an internal data base of local historical $\mathrm{ET}_{0}$, or real $\mathrm{ET}_{\mathrm{o}}$ can be calculated from manual input, of climate data. The VegSyst model simulates $\mathrm{ET}_{c}$, crop growth and crop $\mathrm{N}$ uptake of greenhouse-grown vegetable crops (Gallardo et al., 2011, 2016). This model has been adapted to create a Decision Support System (DSS) for combined irrigation and $\mathrm{N}$ management of vegetables in Mediterranean greenhouses (Gallardo et al., 2014) that worksinWindows (https://w3.ual.es/GruposInv/nitrogeno/ VegSyst-DSS.shtml).

For Dutch greenhouse horticulture, De Graaf and Van den Ende (1981) developed a simple ET $_{\mathrm{c}}$ model with inputs that are commonly available data in commercial greenhouse production. This approach was subsequently improved and is now widely used for irrigation scheduling in commercial practice in The Netherlands (De Graaf, 1988; Voogt et al., 2000; Thompson et al., 2017b).

Barriers for the wider adoption of $\mathrm{ET}_{\mathrm{c}}$-based irrigation scheduling techniques, by commercial vegetable growers, are: (i) the time required to make the calculations; (ii) the practical difficulties associated with the use of software; (iii) the common lack of effective procedures to train growers; (iv) the lack of on-going technical support; and (v) that growers are reluctant to take what they perceive as a risk with value crops that are sensitive to crop water stress (Gallardo et al., 2013; Cahn and Johnson, 2017).

\section{Use of soil moisture sensors for irrigation scheduling}

Soil moisture sensors enable irrigation management to be adjusted to the particular characteristics of individual crops and fields. The sensors and the associated data interpretation can be managed by growers; however, private webbased services are increasingly being used to assist with sensor management and data interpretation. Soil moisture sensors are useful tools for vegetable crops irrigated with high frequency systems (e.g., drip irrigation) where soil moisture is often maintained within a narrow range of soil moisture, close to field capacity. Generally, soil sensors are useful in determining when to irrigate, but they are less useful for estimating the volume of irrigation because of the heterogeneity of soil water content, particularly with drip-irrigated crops. Soil moisture sensors can be used as a "stand-alone" method, or can be combined with the previously-described FAO method to estimate crop water requirements.

The current soil sensor technologies are described by Thompson and Gallardo (2003), Charlesworth (2005), Pardossi et al. (2009) and Gallardo et al. (2013). The use of these sensors for irrigation scheduling is discussed by Hansen et al. (2000), Thompson and Gallardo (2003), Evett (2007), Gallardo et al. (2013) and Cahn and Johnson (2017). Sensors measure soil matric potential (SMP) or volumetric soil water content (VSWC). A useful and simple sensor, the "Full Stop sensor", can be used to determine when sufficient irrigation has been applied by indicating the arrival of the wetting front at a given depth (Charlesworth, 2005; Stirzaker et al., 2009; Thompson et al., 2015).
Generally, for both SMP and VSWC sensors, lower limit or threshold values are used to identify when to irrigate and upper limit values to identify when irrigation is sufficient (Thompson and Gallardo, 2003; Gallardo et al., 2013; Thompson et al., 2015, 2017b). Most commonly, fixed irrigation volumes are applied; automatic control of the applied volume requires very frequent measurement with sensors that have rapid response times. Tendencies over time can be used to adjust irrigation volumes (Thompson and Gallardo, 2003; Gallardo et al., 2013; Thompson et al., 2015). Irrigation scheduling with SMP is relatively straightforward (Gallardo et al., 2013); lower limit SMP values for given crops are generally applicable for a range of soil types and conditions. Lower limit SMP values are commonly available in scientific and extension literature (e.g., Hansen et al., 2000; Locascio, 2005; Shock et al., 2007) or can be determined for a given crop in a given system (e.g., Thompson et al., 2007a). Commonly for vegetable crops, lower limits of SMP are >-50 kPa (Locascio, 2005; Thompson et al., 2007a). Adjustments to recommended lower limit SMP values may be required to consider evaporative demand and soil texture (Hansen et al., 2000; Locascio, 2005). Limits for VSWC need to be determined in situ, or at least locally in representative conditions, by using dynamic protocols (Thompson et al., 2007b) or by conducting small studies (Thompson et al., 2007a); relevant procedures are described by Charlesworth (2005) and by Thompson et al. (2007a, b).

The two types of soil matric potential sensors (SMP) sensors most suitable for drip irrigated vegetable crop are tensiometers and granular matrix sensors. Tensiometers are cheap, simple and easy to use. However, they require preparation and maintenance to provide accurate and reliable data (Thompson and Gallardo, 2003; Gallardo et al., 2013) which can be a practical drawback for growers. The relatively narrow working range of most tensiometers of 0 to $-80 \mathrm{kPa}$ is generally adequate for frequently irrigated vegetable crops, but can be a limitation where soils dry out quickly (Gallardo et al., 2013). With vegetable crops receiving very frequent drip irrigation, it is possible to maintain SMP within this range, depending on soil type and climatic conditions. Tensiometers can be read manually or used with pressure transducers, or relay to automatically initiated irrigation.

Granular matrix (GM) sensors measure the electrical resistance between two electrodes in a porous matrix; the resistance being a function of the soil matric potential (Charlesworth, 2005; Thompson et al., 2006). The most commonly-used is the Watermark sensor (Irrometer Co. CA, USA). A hand-held reader can be used to supply the current, interpret the signal, and read values. Data can be input directly to an irrigation controller. GM sensors are cheap, simple, easy to install with little preparation and maintenance requirements. The measuring range is from -10 to $-200 \mathrm{kPa}$. While they have a wider measurement range than tensiometers, they are inaccurate in wet soils (from 0 to $-10 \mathrm{kPa}$ ) and have a slower response in soils that dry quickly (Thompson et al., 2006). In general, GM sensors are less accurate than tensiometers but require appreciably less attention (Thompson et al., 2006).

Recently, sensors based on Frequency Domain Reflectometry (FDR) technology have been developed to measure soil matric potential (Gallardo et al., 2013). Examples are the MPS family of sensors (Decagon Devices, WA, USA) which provide measurement of SMP over a very wide working range (from -9 to $-100,000 \mathrm{kPa}$ ) and have no maintenance requirements. Currently, limited data are available evaluat- 
ing SMP sensors based on FDR technology.

For the measurement of volumetric soil water content (VSWC), there is a large and constantly changing number of commercially available sensors. Most of these are di-electric sensors. There are two general types of di-electric sensors: (i) Time Domain Reflectometry (TDR), and (ii) Capacitance, or FDR sensors. TDR sensors, while widely used in research, are little used for irrigation management because of limitations of the cable length from sensors to associated electronic equipment, and the difficulties of measuring at depths of greater than approximately $30 \mathrm{~cm}$ (Thompson and Gallardo, 2003). Capacitance (or FDR) sensors are widely used for irrigation management. Capacitance sensors are available in several different configurations, e.g., probes of various centimeters length or rings mounted at various depths on a vertical probe (Charlesworth, 2005; Thompson and Gallardo, 2003).

There are various formats for VSWC sensors, stand-alone mode, connected to data loggers, or connected directly to irrigation controllers (Thompson and Gallardo, 2003). VSWC sensors with frequent measurement and fast response times can be used to automatically initiate and stop irrigation. Sensitivity to changes in soil salinity has been reported for Capacitance sensors (Cardenas-Lailhacar and Dukes, 2015; Thompson et al., 2007c), which can affect their use with vegetable crops where salinity is managed to increase fruit quality. Thompson et al. (2007c) reported $4.0-7.5 \%$ relative increases in measured VSWC values for every $1 \mathrm{dS} \mathrm{m}^{-1}$ increase in soil solution electrical conductivity. It has been suggested that Capacitance sensors with higher operating frequencies are less sensitive to salinity (Regalado et al., 2010).

Some VSWC sensors also measure bulk soil electrical conductivity (EC) (Gallardo et al., 2013). Simultaneous continuous measurement of bulk soil EC, together with VSWC, can potentially be used for soil salinity and nutrient management of fertigated crops. Caution should be taken regarding bulk soil EC data since soil bulk EC data are difficult to interpret for practical salinity management, and conversions are required to obtain equivalent soil solution extract EC values (Gallardo et al., 2013). While there are uncertainties regarding absolute soil solution EC values derived from bulk soil EC measurement, tendencies over time can assist with soil salinity and nutrient management of fertigated vegetable crops (Gallardo et al., 2013).

A number of studies have evaluated the use of soil moisture sensors to automatically control irrigation in vegetable crops; in these studies automatic controllers initiated irrigation when the drying soil reached a predetermined threshold value (Dukes et al., 2010; Munoz-Carpena et al., 2008). The controllers were based on SMP (Dukes and Scholberg, 2005; Munoz-Carpena et al., 2005) or on VSWC (Munoz-Carpena et al., 2008). In these studies, particularly those conducted on sandy soil, Capacitance sensors were generally more reliable than tensiometers and GM sensors for automatic control of irrigation (Dukes et al., 2010). Advantages in water saving and yield improvement from automatic irrigation were reduced when going from smaller to larger fields (Cahn and Johnson, 2017).

Some limitations to the use of soil moisture sensors for irrigation scheduling of vegetable crops are: (i) the total additional cost when using real-time monitoring and the labor for installation; (ii) the lack of information about the volume of water to apply; and (iii) spatial variability that is most apparent with drip irrigation (Thompson and Gallardo, 2003; Gallardo et al., 2013). Despite these limitations, soil moisture sensors are being used in commercial farming and their use is increasing. They can be considered to be a very promising tool for irrigation scheduling in vegetable crops.

\section{Tools and approaches to optimize $\mathrm{N}$ fertilization}

Numerous uncertainties influence the economically optimal rates and timing of nitrogen $(\mathrm{N})$ fertilizer application for vegetable crops (Thompson et al., 2017a). Variations in growing periods, planting dates and crop management practices create variations in the crop demand for N. Crop available $\mathrm{N}$ supplied by sources such as (a) soil mineral $\mathrm{N}$ at planting, and (b) $\mathrm{N}$ mineralization from various organic sources (soil organic matter, soil amendments, crop residues) during the growing period, further influence the optimal amount of supplemental $\mathrm{N}$ required as mineral fertilizer (Soto et al., 2015; Thompson et al., 2017a). Generally, in commercial practice, the rates and timing of mineral $\mathrm{N}$ fertilizer addition are based on the experience of vegetable growers and their advisors (Thompson et al., 2007d), and excessive mineral $\mathrm{N}$ fertilizer, commonly applied to ensure the various uncertainties, do not cause deficient applications that would reduce crop yields (Thompson et al., 2017a).

Optimal $\mathrm{N}$ management requires the appreciable reduction of these uncertainties, which can be achieved through the provision of information (Thompson et al., 2017a). The appropriate tools and approaches for a given crop/location will depend on the crops being grown, the skills of the grower, the local availability of suitable approaches and tools, the availability of support services (e.g., analytical laboratories, technical support), and economic considerations (Thompson et al., 2017a). Increasingly, legislation is obliging vegetable growers to adopt recommendation schemes and tools to improve crop $\mathrm{N}$ management. The main categories of available local recommendation schemes and tools for $\mathrm{N}$ management, for use with vegetable crops are: (1) soil testing approaches; (2) soil solution analysis; (3) N balance calculations; (4) decision support systems; and (5) crop/ plant testing approaches (Thompson et al., 2017a, b). All methods are described subsequently.

\section{Soil testing approaches}

With soil testing approaches, the $\mathrm{N}$ fertilizer rate is adjusted in response to the amount of soil mineral $\mathrm{N}$ in the root zone. These methods are commonly used with open field vegetable crops in North-Western and Central Europe; the most used systems are the $\mathrm{N}_{\text {min }}$, KNS and N-Expert methods. Common to these three methods is the " $\mathrm{N}$ target value" which represents the required total mineral $\mathrm{N}$ supply (Thompson et al., 2017a). Nitrogen supplied by the soil is subtracted from the "N target value" to calculate the mineral $\mathrm{N}$ fertilizer application rate.

The $\mathrm{N}_{\min }$ method is the simplest of these methods and only estimates a single rate for the entire crop (Thompson et al., 2017a). The KNS method is based on the amount of soil mineral $\mathrm{N}$ content throughout a crop (at planting and at least once during the crop) and crop $\mathrm{N}$ uptake (Ziegler et al., 1996; Thompson et al., 2017a). There is an assumption of a minimum buffer value of root zone soil mineral $\mathrm{N}$ below which production is N-limited; buffer values vary with species and crop growth. The buffer value is added to the anticipated $\mathrm{N}$ uptake for a given period (e.g., several weeks) to calculate the $\mathrm{N}$ target value for that period. Crop $\mathrm{N}$ uptake curves with short time intervals (e.g., weekly) are used. Soil mineral $\mathrm{N}$ present, at each sampling, is subtracted from the calculated $\mathrm{N}$ target value, for the next period, to calculate the 
amount of $\mathrm{N}$ fertilizer to apply. Commonly, $\mathrm{N}$ mineralization is also included in the soil $\mathrm{N}$ supply, most simply by assuming a fixed rate of $\mathrm{N}$ mineralization, often a value of $5 \mathrm{~kg} \mathrm{~N}$ ha $^{-1}$ week $^{-1}$ (Feller and Fink, 2002). The KNS is essentially a $\mathrm{N}$ balance method (Thompson et al., 2017a). The N-Expert System (Feller, 2017) which is a computer-operated Decision Support System (DSS) used for recommendations for vegetable crops in Germany, is a further development of the KNS system.

The Pre Side-dress Nitrate Test (PSNT) used in the USA and Canada measures root zone soil $\left[\mathrm{NO}_{3}^{-}\right]$(generally to $30 \mathrm{~cm}$ ) during the crop immediately prior to the main side-dressing $\mathrm{N}$ application (Meisinger et al., 2008; Thompson et al., 2017a) and has been recommended for vegetable crops in California (Hartz, 2003, 2006; Hartz and Bottoms, 2009). Its primary use is to decide if side-dress $\mathrm{N}$ fertilizer is required (Meisinger et al., 2008, Thompson et al., 2017); although Hartz and Bottoms (2009) suggested a procedure to calculate the rate of fertilizer $\mathrm{N}$ when the PSNT indicates that the soil is deficient in $\mathrm{N}$.

An approach related to soil testing, is the use of indices of soil $\mathrm{N}$ supply, which is an estimation of soil $\mathrm{N}$ supply based on soil texture, climate and site history (Thompson et al., 2017a). The RB209 recommendation system used in England and Wales uses this approach (AHDB, 2017; Thompson et al., 2017a); it also has provision for soil analysis. The RB209 recommendation scheme can be used as smartphone App or can be downloaded as a PDF file.

\section{Soil solution analysis}

Ceramic cup suction soil solution samplers can be used for on-going $\mathrm{N}$ management of vegetable crops by regularly sampling the soil solution in order to control the soil solution $\left[\mathrm{NO}_{3}^{-}\right]$in the immediate root zone. This method is well suited for use with vegetable crops receiving frequent nutrient addition through fertigation/drip irrigation (Thompson et al., 2017a, b). Hartz and Hochmuth (1996) suggested its use in vegetable crops with a minimum threshold value of $5 \mathrm{mmol} \mathrm{L}^{-1}$. Granados et al. (2013) suggested a sufficiency range of 8-12 $\mathrm{mmol} \mathrm{L}^{-1}$ for greenhouse vegetable crops; subsequent studies have suggested lower minimum threshold values (Thompson et al., 2017a).

Hartz (2003) commented that the spatial variability of soil solution $\left[\mathrm{NO}_{3}^{-}\right]$was an issue for the practical use of suction samplers. Granados et al. (2013) reported that spatial variability could be appreciably reduced through careful site selection and replication. In greenhouse-grown vegetable crops with frequent $\mathrm{N}$ application through fertigation/ drip irrigation, excessive $\mathrm{N}$ application was associated with increasing soil solution $\left[\mathrm{NO}_{3}^{-}\right.$] (Gallardo et al., 2006c; Granados et al., 2013; Peña-Fleitas et al., 2015). These results suggested that an on-going tendency of increasing soil solution $\left[\mathrm{NO}_{3}{ }^{-}\right]$is a sensitive indicator of excessive $\mathrm{N}$ application with fertigated/drip irrigated vegetable crops, particularly where little drainage and therefore little $\mathrm{NO}_{3}^{-}$leaching occurs (Thompson et al., 2017a, b). The use of tendencies overcomes the uncertainties associated with spatial variation of individual point measurements and of identifying threshold values (Thompson et al., 2017a, b).

Small portable "quick test" systems (Thompson et al., 2009; Parks et al., 2012) enable on-farm determination of the $\left[\mathrm{NO}_{3}^{-}\right]$. With rapid analysis system, care must be taken and results should be periodically checked against laboratory analysis. Combining the use of the suction samplers with on-farm use analysis with "quick test" systems enables rapid assessment of the immediately available $\mathrm{N}$ supply in the root zone (Thompson et al., 2017a, b).

The 1:2 by volume soil-water extract method (Sonneveld et al., 1990; Sonneveld and Voogt, 2009; Thompson et al., $2017 \mathrm{a}, \mathrm{b}$ ) is used in Dutch greenhouses for the management of $\mathrm{N}$ and other nutrients of soil-grown fertigated crops. It recently has been adapted for use by greenhouse growers in Italy (Thompson et al., 2017a, b). In Italy, the application of the 1:2 extract method is facilitated by the user-friendly GreenFert software (http://www.cespevi.it/softunipi/greenfert. html) developed by Incrocci and colleagues at the University of Pisa.

\section{$\mathrm{N}$ balance calculation}

The $\mathrm{N}$ balance calculates the amount(s) of mineral $\mathrm{N}$ fertilizer to be applied for an entire crop or for periods within a crop (Thompson et al., 2017a, b). The determination of $\mathrm{N}$ fertilizer application amount using $\mathrm{N}$ balance calculations has the advantage of explicitly considering all major $\mathrm{N}$ inputs, such as crop available $\mathrm{N}$ supplied by the soil, and from additions of organic material (manure, crop residues) (Thompson et al., 2017a, b). In its simplest form, $\mathrm{N}$ balances are calculated for the entire crop. With the use of simulation models, $\mathrm{N}$ balances can be calculated daily or weekly, enabling site, crop and season specific $\mathrm{N}$ management (Thompson et al., 2017a, b). When used with daily or weekly time steps, $\mathrm{N}$ balance calculations can be used in production systems with frequent $\mathrm{N}$ application through fertigation/drip irrigation systems (Thompson et al., 2017a, b). Additional soil analyses can be used as feedback to adjust parameters. The commonly used $\mathrm{N}$ inputs and outputs are listed in Table 1.

For each given time period, the sum of $\mathrm{N}$ inputs equals the sum of $\mathrm{N}$ outputs. The $\mathrm{N}$ balance is used to calculate the amount of $\mathrm{N}$ to apply as mineral fertilizer, using the general approach of equation 1 :

$$
\mathrm{N}_{\text {fert }}=\mathrm{N}_{\text {outputs }}-\mathrm{N}_{\text {inputs }} \text { (apart from } \mathrm{N}_{\text {fert }} \text { ) }
$$

Various approaches have been used to calculate $\mathrm{N}_{\text {fert }}$ (Meisinger et al., 2008; Thompson et al., 2017a, b). N balance calculations form part of recommendation systems such as KNS and of various Decision Support Systems (DSSs), e.g., $\mathrm{N}$-Expert, VegSyst-DSS (see next section). Frequent $\mathrm{N}$ balance calculation, as done in some DSSs, can be used to make frequent $\mathrm{N}$ recommendations that are suitable for fertigated vegetable crops with frequent $\mathrm{N}$ application.

\section{Decision support systems (DSSs)}

A number of decision support systems (DSSs) based on simulation models have been developed to assist with $\mathrm{N}$ fertilization in vegetable crops (Thompson et al., 2017a, b). These DSSs can be stand-alone or web-based programs; web-based programs can be consulted by any device with an Internet connection. Computer technology enables numerous and frequent calculations to be made, numerous inputs to be considered, the use of stored data records, record keeping and the inclusion of simulation models (Thompson et al., 2017a, b). Most relevant DSSs are based on simulation models. Two broad modelling approaches are used with DSSs. They generally are either "static" in which standard conditions are assumed such as expected yield and average climatic conditions, or "dynamic" in which real time or forecast climatic data are used (Incrocci et al., 2017; Thompson et al., 2015, 2017a, b). Static approaches are simpler and require less data because numerous data inputs are assumed. Dy- 
TABLE 1. $\mathrm{N}$ inputs and outputs used for developing an $\mathrm{N}$ balance.

\begin{tabular}{ll}
\hline $\mathrm{N}$ Inputs & $\mathrm{N}$ Outputs \\
\hline Initial soil mineral $\mathrm{N}\left(\mathrm{N}_{\text {min-inin }}\right)$ & Crop $\mathrm{N}$ uptake $\left(\mathrm{N}_{\text {crop }}\right)$ \\
$\mathrm{N}$ mineralized from soil OM $\left(\mathrm{N}_{\text {minz-om }}\right)$ & $\mathrm{N}$ losses $\left(\mathrm{N}_{\text {loss }}\right)$ \\
$\mathrm{N}$ mineralized from org. residues $\left(\mathrm{N}_{\text {minz-res }}\right)$ & Final soil mineral $\mathrm{N}\left(\mathrm{N}_{\text {min-fin }}\right)$ \\
Mineral $\mathrm{N}$ fertilizer $\left(\mathrm{N}_{\text {fert }}\right)$ & \\
\hline Total $\mathrm{N}$ Inputs $\left(\sum\right.$ Inputs $)$ & Total N Outputs $\left(\sum\right.$ Outputs) \\
\hline
\end{tabular}

namic models respond to actual or forecasted cropping conditions, and therefore are more complex and require more input data. Some DSSs use both approaches and give the user the option of selecting one approach, e.g., VegSyst-DSS (Gallardo et al., 2014, 2016). DSSs come with varying degrees of complexity. Relatively simple DSSs with few data requirements are well suited for on-farm use (Parneaudeau et al., 2009; Gallardo et al., 2014; Thompson et al., 2015, 2017a).

The N-Expert4 (Feller, 2017) and AzoFert ${ }^{\circledR}$ (Parneaudeau et al., 2009) DSSs are widely used in Germany and France, respectively, for calculating $\mathrm{N}$ fertilizer recommendations. A number of DSSs calculate both $\mathrm{N}$ fertiliser and irrigation requirements, generally for specific systems, e.g., GesCoN for fertigated vegetable crops in Mediterranean regions (Elia and Conversa, 2015), VegSyst-DSS for fertigated vegetable crops in Mediterranean greenhouses (Gallardo et al., 2014, 2016), and CropManage (Cahn et al., 2013) which has been developed for irrigation and $\mathrm{N}$ fertiliser requirements of fertigated open-field leafy vegetables in the central coast of California. More information on relevant available DSSs are available in Incrocci et al. (2017) and Thompson et al. (2015, 2017a, b).

\section{Crop and plant monitoring approaches}

Monitoring of crop or plant N status potentially can provide information on the adequacy of the $\mathrm{N}$ supply in relation to the $\mathrm{N}$ demand (Schröder et al., 2000; Thompson et al., $2017 \mathrm{a}, \mathrm{b}$ ). While total $\mathrm{N}$ analysis of leaf tissue (leaf analysis) is an established method, it is not well suited to frequent monitoring of vegetable crops grown with fertigation, which is increasingly being used in vegetable production (Thompson et al., 2017a, b). Leaf analysis is unsuitable with fertigated crops because of the logistics of sending samples to analytical laboratories, the time delay in obtaining results, and the reported limited sensitivity to recent changes in crop N status (Olsen and Lyons, 1994; Thompson et al., 2017a). Hereafter, only methods that can be used frequently and quickly to assess crop $\mathrm{N}$ status of fertigated vegetable crops will be presented; such method will enable rapid correction of crop N status.

\section{Petiole sap $\left[\mathrm{NO}_{3}{ }^{-}\right]$analysis}

Petiole sap $\left[\mathrm{NO}_{3}^{-}\right]$has been proposed as an indicator of crop $\mathrm{N}$ status of vegetable crops. It is a very sensitive indicator of crop N status, particularly of $\mathrm{N}$ deficiency (Peña-Fleitas et al., 2015; Thompson et al., 2017a). Strict protocols are required for sampling, handling and storing of the plant material (petioles), and for the extraction and storage of sap samples (Goffart et al., 2008; Hochmuth, 1994, 2012; Thompson et al., 2017a). Analysis can be made rapidly on the farm using quick test systems (Hochmuth, 1994; Thompson et al., 2009, 2012, 2017a; Parks et al., 2012). With rapid analysis systems, considerable care must be taken, and results should be periodically checked against laboratory analyses.
Sufficiency ranges for a number of important vegetable species, at different phenological stages, have been published for Florida, USA (Hochmuth, 1994, 2012), but otherwise there are limited publicly available data of sufficiency ranges and values (Thompson et al., 2017a). The reported values of the sufficiency range generally decline as the crop grows, and recommendations are normally given for specific phenological stages (e.g., Hochmuth, 1994, 2012). Sap [ $\left.\mathrm{NO}_{3}{ }^{-}\right]$ values can be affected by factors such as amount and timing of $\mathrm{N}$ previous application, and crop water status (Goffart et al., 2008). Given such sensitivity to various factors, it is generally considered that sap $\left[\mathrm{NO}_{3}{ }^{-}\right]$recommendations should be developed specifically for individual species for individual regions and cropping systems (Goffart et al., 2008; Thompson et al., 2017a). For example, the results of Farneselli et al. (2014) suggested that petiole sap $\left[\mathrm{NO}_{3}^{-}\right]$was a good indicator of crop N status for processing tomato in central Italy.

Whereas earlier studies, presumably conducted with pre-planting and a small number of side-dress applications, reported declining sufficiency ranges/values during a crop (Hochmuth, 1994, 2012), recent studies with fertigated tomato and muskmelon crops (Farneselli et al., 2014; Peña-Fleitas et al., 2015) have suggested that fertigated crops receiving frequent $\mathrm{N}$ application can: (a) maintain sap $\left[\mathrm{NO}_{3}^{-}\right]$throughout much of the crop cycle; and (b) maintain strong and similar linear relationships between petiole sap $\left[\mathrm{NO}_{3}^{-}\right]$and crop $\mathrm{N}$ status, assessed as the Nitrogen Nutrition Index (NNI; Lemaire et al., 2008), throughout individual crops. Additionally, in these studies, similar relationships between sap $\left[\mathrm{NO}_{3}^{-}\right]$ and NNI were observed in different tomato crops grown in very different conditions, and a common sufficiency value was derived for much of the growth cycle of these diverse tomato (Peña-Fleitas et al., 2015). These results suggest that petiole sap $\left[\mathrm{NO}_{3}^{-}\right.$] may behave differently in crops receiving frequent $\mathrm{N}$ application by fertigation compared to crops receiving traditional pre-plant and side-dress $\mathrm{N}$ applications (Thompson et al., 2017a). They further suggest that with fertigated crops, petiole sap $\left[\mathrm{NO}_{3}{ }^{-}\right]$sufficiency values and ranges may be relatively constant throughout much of a crop cycle and that sufficiency values and ranges may be common for a given species grown under different conditions (Thompson et al., 2017a). Further work is required to examine the potential for using sap $\left[\mathrm{NO}_{3}{ }^{-}\right]$analysis for monitoring crop $\mathrm{N}$ status of vegetable crops grown with high frequency $\mathrm{N}$ application through fertigation/drip irrigation (Thompson et al., 2017a).

Recently, commercial laboratories in The Netherlands have developed rapid services for plant sap testing, using sap from leaves; analytical results are provided within 2-3 days (W. Voogt, pers. commun., 2017; Thompson et al., 2017a). Growers have reported that using this method they have reduced $\mathrm{N}$ application while maintaining production (W. Voogt, pers. commun., 2017). However, it has not been possible to scientifically validate these procedures (Thompson et al., 2017a). Also, there are very few published studies on sap 
obtained from leaves; most reported studies have used sap from petioles (Thompson et al., 2017a).

\section{Chlorophyll meters}

Chlorophyll meters (CMs) are small, hand-held, clipon optical sensors that indirectly measure leaf chlorophyll which is correlated to leaf $\mathrm{N}$ content. CMs readings have been reported to be sensitive to crop N status (Goffart et al., 2008; Thompson et al., 2017a). There are several commercially available sensors; most work has been done with the SPAD-502 (Konica-Minolta, Tokyo, Japan) and the Hydro $\mathrm{N}$-tester (Yara International, Oslo, Norway). Given their ease of use, relatively low cost, suitability for frequent measurement, and general sensitivity to crop $\mathrm{N}$ status of vegetable crops (Goffart et al., 2008; Padilla et al., 2014, 2015, 2017a), these sensors appear to have potential for use with vegetable crops. In general, it appears that they are likely to be most effective when used with a specific species in a specific region (Goffart et al., 2008; Thompson et al., 2017a). They are robust and sensitive to $\mathrm{N}$ deficiency (Padilla et al., 2014, 2015, 2017a; Thompson et al., 2017a), and the recent availability of threshold values (e.g., Padilla et al., 2015, 2017a) may facilitate more use in commercial vegetable production.

\section{Canopy reflectance sensors}

In recent years, there has been considerable research on the use of proximal canopy reflectance sensors to assist with crop $\mathrm{N}$ management of diverse crop species (e.g., Fox and Walthall, 2008; Meisinger et al., 2008; Samborski et al., 2009). Proximal sensors are commonly positioned 0.4-3.0 m from the crop canopy. While most of the research on the use of proximal canopy reflectance sensors has been with cereal crops (Fox and Walthall, 2008; Meisinger et al., 2008; Samborski et al., 2009), there have been some studies with vegetable crops (e.g., Gianquinto et al., 2011; Padilla et al., 2014, 2015, 2017b). Canopy reflectance sensors are being used for $\mathrm{N}$ management on commercial cereal farms, particularly for variable rate fertilizer application. Most of the sensors being currently used (e.g., Crop Circle sensors (Holland Scientific, Inc., Lincoln, NE, USA) and Greenseeker sensors (Trimble Navigation Ltd., Sunnyvale, CA, USA), (Thompson et al., 2017a), are active sensors with their own light source and can be used in any light conditions. The big advantage of proximal reflectance sensors is that they measure large representative areas of the crop because of the relatively large measurement window and continual measurement (Thompson et al., 2017a).

Canopy reflectance measurements are based on the interaction of different visible and NIR (near infrared) wavelengths with the crop canopy (Fox and Walthall, 2008; Samborski et al., 2009). The reflectance of 2-3 individual wavelengths are used to derive mathematical indices known as vegetation indices. There are numerous indices; the most commonly used is the NDVI (Normalized Difference Vegetation Index). A commonly used procedure to interpret these data is to compare measured indices with $\mathrm{N}$ rich areas in which $\mathrm{N}$ is not limiting (Fox and Walthall, 2008; Thompson et al., 2017a). However, this implies that, when crop N status is excessive, sensor readings have a plateau response (Thompson et al., 2017a); this was not observed with muskmelon (Padilla et al., 2014), suggesting that it is not common to all vegetable species. The development of protocols to assess crop $\mathrm{N}$ status and to determine $\mathrm{N}$ fertilizer application rates, of canopy reflectance and other optical sensors, is an active area of research (Thompson et al., 2017a). Padilla et al. (2015, 2017b) developed approaches for determining threshold values for both maximum growth and yield of vegetable crops. Using these approaches, threshold values were determined for tomato (Padilla et al., 2015) and cucumber (Padilla et al., 2017b).

Canopy reflectance sensors are a promising approach for evaluating crop $\mathrm{N}$ status of vegetable crops. However, unlike with cereal crops, relatively little research has been done with vegetable crops and more research is required to develop effective protocols and threshold values. Their capacity for frequent, rapid and representative measurement, and their current use in commercial cereal crops suggest that these sensors have considerable potential for use with fertigated vegetable crops (Thompson et al., 2017a, b).

\section{Potential role of plant biostimulants and grafting on improving water and nutrient use efficiency}

\section{Plant biostimulants}

The use of natural plant biostimulants have been proposed as sustainable and meaningful approach to enhance abiotic stress tolerance, fruit quality traits, as well as nutrient use efficiency (Colla and Rouphael, 2015; Rouphael et al., 2017b, c, d). Plant biostimulants correspond to natural substances and microorganisms (Colla and Rouphael, 2015). They are classified in five categories including humic acids, seaweed extracts, protein hydrolysates, mycorrhizal fungi and plant growth promoting rhizobacteria with strains belonging to genera Azospirillum, Azotobacter and Rhizobium spp. (Colla et al., 2014, 2015b; Rouphael et al., 2015).

Plant biostimulants have been claimed to activate under water and nutrient stress conditions, a series of biochemical and physiological mechanisms such as enhancement of leaf water relations, increase in the relative water content and pigments biosynthesis as well as reducing stomatal limitation, which in turn led to higher water and nutrient uptakes (Colla et al., 2013a; Xu and Leskovar, 2015; Abd El-Mageed et al., 2017).

In a recent study Abd El-Mageed et al. (2017) demonstrated that the foliar application of leaf extract of Moringa oleifera at a dose of $3 \%$ was effective in mitigating the negative effect of water stress (i.e., irrigation with 60 or $80 \%$ of $\mathrm{ET}_{\mathrm{c}}$ ) in zucchini squash. A presumed mechanism involved in the stimulation of crop performance under water stress conditions might be the capability of maintaining higher chlorophyll fluorescence, pigments biosynthesis, and relative water content, leading to a higher WUE. Increases in growth in response to Ascophyllum nodosum seaweed extracts application methods (foliar, drench or their combination) have also been observed in spinach (Xu and Leskovar, 2015). The authors associated the increase in crop performance to an improvement of leaf water relations and to a reduction in stomatal limitations, which in turn led to high photosynthetic activity and plant growth rate.

Plant biostimulants could also help in reducing fertilizer application in several leafy vegetables and consequently help to realize to a lower impact on the environment (Vernieri et al., 2006; Colla et al., 2013a). For instance, the addition of a commercial plant biostimulant 'Actiwave' at $0.3 \mathrm{~mL} \mathrm{~L}^{-1}$ in a quarter-strength standard nutrient solution (25\%) exhibited similar yield of rocket compared to the full strength nutrient solution $(100 \%)$. Furthermore, plant biostimulant application increased nutrient uptake and nutrient use efficiency 
in all treatments $(100 \%, 25 \%$ and $10 \%$ nutrient concentration). Similarly, at low nutrient solution concentration $(10 \%$ of the basic nutrient solution), weekly foliar application of a commercial protein hydrolysate 'Trainer' incurred significant increase in fresh yield, SPAD index and leaf total nitrogen by $50 \%, 11 \%$ and $12 \%$, respectively (Colla et al., 2013a). The application of plant biostimulant, in particular protein hydrolysate, may have influenced $\mathrm{N}$ metabolism in plant via the activation of $\mathrm{N}$ assimilation-related key enzymes (Colla et al., 2015b).

Water use efficiency increase by microbial biostimulants, in particular arbuscular mycorrhiza fungi (AMF), has also been reported on several vegetable crops. For example, the WUE was higher in inoculated (Funneliformis mosseae BEG25, Funneliformis geosporus BEG11 or a 50:50 mixed inoculation treatment of both species) strawberry plants than in non-inoculated plants under water stress conditions (Boyer et al., 2015). Similarly, inoculation with a mixed inoculum of Glomus intraradices and Glomus mosseae has been reported to improve yield and WUE by $20 \%$ in watermelon under water stress conditions compared to non-inoculated plants (Omirou et al., 2013). The increase in root growth, the improvement in root system morphology (root diameter, total root length and diameter) and the development of external mycelium may have enhanced nutrient availability, uptake and translocation of the inoculated plants (Cardarelli et al., 2010; Rouphael et al., 2010).

\section{Grafting}

Grafting is a well-known agronomic practice used to enhance productivity, to ameliorate abiotic and biotic stresses and also to improve water and nutrient use efficiency of vegetables, particularly for Cucurbitaceae and Solanaceae crops (Colla et al., 2010a, 2012, 2013b; Rouphael et al., 2012, 2016b, 2018c; Kumar et al., 2015a, b, 2017).

In a recent study, Liu et al. (2016) reported that luffa (Luffa cylindrica Roem. cv. Xiangfei No. 236) rootstock resulted in a higher instantaneous WUE, when grafted with its own scion or with cucumber (Cucumis sativus L. cv. Jinyan No. 4). In the case of tomato, scion of cv. Faridah grafted onto the interspecific tomato hybrid 'Unifort' (Solanum lycopersium L. $\times$ Solanum pimpinellifolium L.) incurred significant increase in WUE under both full and deficit irrigation conditions (Ibrahim et al., 2014; Al-Harbi et al., 2016). In addition, grafting mini-watermelon (Citrullus lanatus (Thunb.) Matsum. \& Nakai, cv. Ingrid) onto pumpkin rootstock (Cucurbita maxima Duch. $\times$ C. moschata Duch., cv. PS1313) increased biomass and WUE by $7-10 \%$ under full and deficit irrigation regimes (Rouphael et al., 2008). Finally, López-Marín et al. (2017) assessed the agronomical and physiological responses of greenhouse sweet pepper cv. Herminio non-grafted or grafted onto three hybrid rootstocks, 'Atlante', 'Creonte' and 'Terrano' under two irrigation treatments $\left(100 \%\right.$ or $50 \%$ of $\left.\mathrm{ET}_{\mathrm{c}}\right)$. The authors reported that among the three rootstocks tested 'Creonte' was the most effective in improving WUE.

The above mentioned research findings demonstrate that the improvement of water uptake and WUE induced by the selected rootstock(s) may be associated to several mechanisms like: (i) deep and vigorous root apparatus in terms of root length, density and surface area; (ii) better nutrient uptake and translocation related to the increased soil exploitation; (iii) enhanced root exudation of organic acids into the soil; (iv) higher antioxidant activity, as well as (v) optimization of water uptake, especially under stress conditions through a greater osmotic adjustment and a better control of stomatal movement (Kumar et al., 2017, and references cited therein).

Selecting rootstocks for high nitrogen and phosphorus acquisition ability may allow decreased $\mathrm{N}$ and $\mathrm{P}$ fertilizer application without affecting the vegetable productivity, minimizing the loss of eutrophying elements (Colla et al., 2010b; Asins et al., 2017). Colla and co-workers (2010b; 2011) conducted a series of short- and long-term experiments under both protected and open field conditions aiming to identify candidate rootstocks capable of improving NUE of the scion in two important cucurbit species such as melon and watermelon. Melon plants grafted onto 'Dinero' and 'Jador' (Cucumis melo L.) and 'P360' (Cucurbita maxima Duchesne $\times$ Cucurbita moschata Duchesne) rootstocks needed 5.7, 5.2 and 6.1 $\mathrm{mM}$ of $\mathrm{NO}_{3}^{-}$, respectively, to reach half maximum shoot dry weight, while melon plants grafted onto 'PS1313' (Cucurbita hybrid) and non-grafted plants needed 9.1 and $13.1 \mathrm{mM}$ of $\mathrm{NO}_{3}{ }^{-}$, respectively (Colla et al., 2010). Similarly, mini-watermelon plants grafted onto 'Macis' (Lagenaria siceraria [Mol.] Standl.), 'PS1313', and 'RP15' (Cucurbita maxima Duchesne $\times$ Cucurbita moschata Duchesne) rootstocks needed 2.3, 2.4, and $2.1 \mathrm{mM} \mathrm{NO}_{3}^{-}$in the nutrient solution, respectively, to reach half maximum shoot dry weight, while plants grafted onto 'Vita' (Lagenaria siceraria [Mol.] Standl.) rootstock and ungrafted plants needed 1.31 and $3.56 \mathrm{mM} \mathrm{NO}_{3}{ }^{-}$, respectively (Colla et al., 2011). In the same experiments, open field trials demonstrated that total and marketable yields as well as NUE and N uptake efficiency were 9.0\%, 8.8\%, 11.8\% and $16.3 \%$ higher in melon 'Proteo' grafted onto 'P360' than in non-grafted plants, respectively. Similarly, Colla et al. (2011) reported that total and marketable yields as well as NUE and $\mathrm{N}$ uptake efficiency incurred a significant increase by $32 \%, 39 \%, 39 \%$ and 38\%, respectively in mini-watermelon 'Minirossa' grafted onto 'Vita' rootstock compared to ungrafted plants. The authors concluded that accurate selection of melon and watermelon rootstocks would represent a sustainable tool for enhancing total and marketable yields as well as NUE and coping with soil fertility concerns under low-input conditions.

In a recent study, Martinez-Andujar and co-workers (2017) conducted a short-term experiment (30 days) aiming to shed light about the mechanism(s) by which four contrasting groups of rootstocks belonging to different genetic backgrounds such as Solanum lycopersicum var. cerasiforme and introgression and recombinant inbred lines derived from the wild relatives Solanum pennellii and Solanum pimpinellifolium under suboptimal P availability $(0.1 \mathrm{mM})$. Rootstocks induced regulation of scion growth under low-P concentration and induced mechanisms that involve both nutritional (P, Ca, $\mathrm{Mg}$ and $\mathrm{Mn}$ ) and hormonal (cytokinins and ethylene) traits. The authors concluded, that among the rootstocks tested $\mathrm{Hp}$ type showing high vigor (i.e., high shoot dry weight) under low-P supply seems to enhance the phosphorus use efficiency, and could be adopted as potential candidate rootstock in breeding programs for increasing productivity under low $\mathrm{P}$ availability (Martinez-Andujar et al., 2017).

\section{Conclusion and future directions}

As reported in this review, many scientific studies have demonstrated the effectiveness of using novel technologies of soil and plant testing, Decision Support Systems (DSSs), and sensors for irrigation management. The main constraints to the commercial application of these tools appear to be the initial cost of these technologies (e.g., sensor technologies), ineffective technology transfer, and the availability 
of effective training and technical support. Many innovative cultural practices such as natural plant biostimulants and grafting can also appreciably affect water and nutrient use efficiency of open-field and greenhouse vegetables. However, the knowledge about the potential benefits derived from applications of these strategies is far from complete.

Future research should focus on innovative, simple and user-friendly DSSs to control both soil/plant water and nutrient status and also to elucidate the Genotype $\times$ Environment $\times$ Management practice interactions to select the best combination(s) able to improve the resource use efficiency in vegetable cropping systems. Moreover, appropriate "dissemination and transfer" actions are needed. Therefore, researchers, extension specialists and growers need to work together to integrate these recent advances in water and nutrient management for balancing the requirements for economic competitiveness and the long-term sustainability of the vegetable industry.

\section{References}

Abd El-Mageed, T., Semida, W.M., and Rady, M.M. (2017). Moringa leaf extract as biostimulant improves water use efficiency, physico-biochemical attributes of squash plants under deficit irrigation. Agric. Water Mgt. 193, 46-54. https://doi.org/10.1016/j. agwat.2017.08.004.

AHDB (2017). Nutrient Management Guide (RB209https://ahdb.org. uk/documents/RB209/RB209_Section6final.pdf.) (accessed October 13, 2017).

Al-Harbi, A., Hejazi, A., and Al-Omran, A. (2016). Responses of grafted tomato (Solanum lycopersicon L.) to abiotic stresses in Saudi Arabia. Saudi J. Biol. Sci. (online, in press). https://doi.org/10.1016/j. sjbs.2016.01.005.

Allen, R.G., Pereira, L.S., Raes, D., and Smith, M. (1998). Crop evapotranspiration. Guidelines for computing crop water requirements. Irrigation and Drainage Paper No. 56. (Rome, Italy: FAO). https://doi.org/10.1016/j.eja.2010.12.001.

Asins, M.J., Albacete, A., Martinez-Andujar, C., Pérez-Alfocea, F., Dodd, I.C., Carbonell, E.A., and Dieleman, J.A. (2017). Genetic analysis of rootstock-mediated nitrogen $(\mathrm{N})$ uptake and root-to-shoot signaling at contrasting $\mathrm{N}$ availabilities in tomato. Plant Sci. 263, 94-106. https://doi.org/10.1016/j.plantsci.2017.06.012.

Boyer, L.R., Brain, P., Xu, X.M., and Jeffries, P. (2015). Inoculation of drought-stressed strawberry with a mixed inoculum of two arbuscular mycorrhizal fungi: effects on population dynamics of fungal species in roots and consequential plant tolerance to water deficiency. Mycorrhiza 25, 215-227. https://doi.org/10.1007/ s00572-014-0603-6.

Cahn, M., and Johnson, L. (2017). New approaches to irrigation scheduling of vegetables. Horticulturae 3, 1-20. https://doi. org/10.3390/horticulturae3020028.

Cahn, M., Smith, R., and Hartz, T. (2013). Improving irrigation and nitrogen management in California leafy greens production. Proc. NUTRIHORT Conference, 16-18 September 2013, Ghent, Belgium. p. 65-68.

Cahn, M., Smith, R., Farrara, B., Hartz, T., Johnson, L., Melton, F., and Post, K. (2014). Irrigation and nitrogen management decision support tool for vegetables and berries. In Proceedings of the U.S Committee on Irrigation and Drainage Conference: Groundwater Issues and Water Management - Strategies Addressing the Challenges of Sustainability (Sacramento, CA, USA: USCID), p. 53-64.

Car, N.J., Christen, E.W., Hornbuckle, J.W., and Moore, G.A. (2012). Using a mobile phone Short Messaging Service (SMS) for irrigation scheduling in Australian farmers participation and utility evaluation.
Comput. Electron. Agric. 84, 132-143. https://doi.org/10.1016/j. compag.2012.03.003.

Cardarelli, M., Rouphael, Y., Rea, E., and Colla, G. (2010). Mitigation of alkaline stress by arbuscular mycorrhiza in zucchini plants grown under mineral and organic fertilization. J. Plant Nutr. Soil Sci. 173, 778-787. https://doi.org/10.1002/jpln.200900378.

Cardenas-Lailhacar, B., and Dukes, M.D. (2015). Effect of temperature and salinity on the precision and accuracy of landscape irrigation soil moisture sensor systems. J. Irrig. Drain. Eng. 141, 04014076. https://doi.org/10.1061/(ASCE)IR.1943-4774.0000847.

Charlesworth, P. (2005). Soil Water Monitoring: An Information Package. Irrigation Insights No. $1,2^{\text {nd }}$ edn. (Canberra, Australia: Land \& Water Australia)

Colla, G., Rouphael, Y., Cardarelli, M., Temperini, O., Rea, E., Salerno, A., and Pierandrei, F. (2008). Influence of grafting on yield and fruit quality of pepper (Capsicum annuum L.) grown under greenhouse conditions. Acta Hortic. 782, 359-363. https://doi.org/10.17660/ actahortic.2008.782.45.

Colla, G., Rouphael, Y., Cardarelli, M., Salerno, A., and Rea, E. (2010a). The effectiveness of grafting to improve alkalinity tolerance in watermelon. Environ. Exp. Bot. 68, 283-291. https://doi. org/10.1016/j.envexpbot.2009.12.005.

Colla, G., Suãrez, C.M.C., Cardarelli, M., and Rouphael, Y. (2010b). Improving nitrogen use efficiency in melon by grafting. HortScience $45,559-565$.

Colla, G., Rouphael, Y., Mirabelli, C., and Cardarelli, M. (2011). Nitrogen-use efficiency traits of mini-watermelon in response to grafting and nitrogen-fertilization doses. J. Plant Nutr. Soil Sci. 174, 933-941. https://doi.org/10.1002/jpln.201000325.

Colla, G., Rouphael, Y., Rea, E., and Cardarelli, M. (2012). Grafting cucumber plants enhance tolerance to sodium chloride and sulfate salinization. Sci. Hortic. 135, 177-185. https://doi.org/10.1016/j. scienta.2011.11.023.

Colla, G., Svecova, E., Cardarelli, M., Rouphael, Y., Reynaud, H., Canaguier, R., and Planques, B. (2013a). Effectiveness of a plantderived protein hydrolysate to improve crop performances under different growing conditions. Acta Hortic. 1009, 175-179. https:// doi.org/10.17660/actahortic.2013.1009.21.

Colla, G., Rouphael, Y., Jawad, R., Kumar, P., Rea, E., and Cardarelli, M. (2013b). The effectiveness of grafting to improve $\mathrm{NaCl}$ and $\mathrm{CaCl}_{2}$ tolerance in cucumber. Sci. Hortic. 164, 380-391. https://doi. org/10.1016/j.scienta.2013.09.023.

Colla, G., Rouphael, Y., Canaguier, R., Svecova, E., and Cardarelli, M. (2014). Biostimulant action of a plant-derived protein hydrolysate produced through enzymatic hydrolysis. Front. Plant Sci. 5, 1-6. https://doi.org/10.3389/fpls.2014.00448.

Colla, G., and Rouphael, Y. (2015). Biostimulants in horticulture. Sci. Hortic. 196, 1-2. https://doi.org/10.1016/j.scienta.2015.10.044.

Colla, G., Rouphael, Y., Di Mattia, E., El-Nakhel, C., and Cardarelli, M. (2015a). Co-inoculation of Glomus intraradices and Trichoderma atroviride acts as a biostimulant to promote growth, yield and nutrient uptake of vegetable crops. J. Sci. Food Agric. 95, 1706-1715. https://doi.org/10.1002/jsfa.6875.

Colla, G., Nardi, S., Cardarelli, M., Ertani, A., Lucini, L., Canaguier, R., and Rouphael, Y. (2015b). Protein hydrolysates as biostimulants in horticulture. Sci. Hortic. 96, 28-38. https://doi.org/10.1016/j. scienta.2015.08.037.

Colla, G., Hoagland, L., Ruzzi, M., Cardarelli, M., Bonini, P., Canaguier, R., and Rouphael, Y. (2017). Biostimulant action of protein hydrolysates: Unraveling their effects on plant physiology and microbiome. Front. Plant Sci. 8, 2202. https://doi.org/10.3389/fpls.2017.02202. 
Colla, G., Cardarelli, M., Bonini, P., and Rouphael, Y. (2017a). Foliar applications of protein hydrolysate, plant and seaweed extracts increase yield but differentially modulate fruit quality of greenhouse tomato. HortScience 52, 1214-1220. https://doi.org/10.21273/ hortsci12200-17.

de Graaf, R. (1988). Automation of the water supply of glasshouse crops by means of calculating the transpiration and measuring the amount of drainage water. Acta Hortic. 229, 219-231. https://doi. org/10.17660/actahortic.1988.229.21.

De Graaf, R., and Van den Ende, J. (1981). Transpiration and evapotranspiration of the glasshouse crops. Acta Hortic. 119, 147157. https://doi.org/10.17660/actahortic.1981.119.13.

De Pascale, S., Dalla Costa, L., Vallone, S., Barbieri, G., and Maggio, A. (2011). Increasing water use efficiency in vegetable crop production: from plant to irrigation systems efficiency. HortTechnology 21, 301307.

De Pascale, S., Rouphael, Y., Pardossi, A., Gallardo, M., and Thompson, R.B. (2017). Recent advances in water and nutrient management of soil-grown crops in Mediterranean greenhouses. Acta Hortic. 1170 31-44. https://doi.org/10.17660/actahortic.2017.1170.3.

Dukes, M.D., and Scholberg, J.M. (2005). Soil moisture controlled subsurface drip irrigation on sandy soils. Appl. Eng. Agric. 21, 89101. https://doi.org/10.13031/2013.17916.

Dukes, M.D., Zotarelli, L., and Morgan, K.T. (2010). Use of irrigation technologies for vegetable crops in Florida. HortTechnology 20, 133-142.

Elia, A., and Conversa, G. (2015). A decision support system ( $\mathrm{Ges} \mathrm{CoN}$ ) for managing fertigation in open field vegetable crops. Part I: Methodological approach and description of the software. Front. Plant Sci. 6, 319. https://doi.org/10.3389/fpls.2015.00319.

Evett, S.R. (2007). Soil water and monitoring technology. In Irrigation of Agricultural Crops (Madison, WI, USA: American Society of Agronomy), p. 270-278.

Farneselli, E., Tei, F., and Simonne, E. (2014). Reliability of petiole sap test for $\mathrm{N}$ nutritional status assessing in processing tomato. J. Plant Nutr. 37, 270-278. https://doi.org/10.1080/01904167.2013.85969 6.

Feller C. (2017). N-Expert - Fertiliser recommendations for field vegetables. http://www.igzev.de/n-expert/?lang=en. (accessed October 13, 2017).

Feller, C., and Fink, M. (2002). $\mathrm{N}_{\min }$ target values for field vegetables. Acta Hortic. 571, 195-201. https://doi.org/10.1080/01904167.201 3.859696 .

Fernández, M.D., Baeza, E., Céspedes, A., Pérez, J., Pérez-Parra, J., and Gázquez, J.C.C. (2009). Validation of on-farm crop water requirements (PrHo) model for horticultural crops in an unheated plastic greenhouse. Acta Hortic. 807, 295-300. https:// doi:10.17660/ActaHortic.2009.807.40.

Fox, R.H., and Walthall, C.L. (2008). Crop monitoring technologies to assess nitrogen status. In Nitrogen in Agricultural Systems (Madison, WI, USA: American Society of Agronomy), p. 647-674.

Gallardo, M., Snyder, R.L., Schulbach, K., and Jackson, L.E. (1996). Crop growth and water use model for lettuce. J. Irrig. Drain. Eng. 122, 354359. https://doi.org/10.1061/(asce)0733-9437(1996)122:6(354).

Gallardo, M., Thompson, R.B., Valdez, L.C., and Fernández, M.D. (2006a). Response of stem diameter variations to water stress in greenhouse-grown vegetable crops. J. Hortic. Sci. Biotechnol. 81, 483-495. https://doi.org/10.1080/14620316.2006.11512092.

Gallardo, M., Thompson, R.B., Valdez, L.C., and Fernández, M.D. (2006b). Use of stem diameter variations to detect plant water stress in tomato. Irrig. Sci. 24, 241-255. https://doi.org/10.1007/s00271005-0025-5.
Gallardo, M., Thompson, R.B., Fernandez, M.D., and López-Toral, J. (2006c). Effect of applied $\mathrm{N}$ concentration in a fertigated vegetable crop on soil solution nitrate and nitrate leaching loss. Acta Hortic. 700, 221-224. https://doi.org/10.17660/actahortic.2006.700.37.

Gallardo, M., Giménez, C., Martínez-Gaitán, C., Stöckle, C.O., Thompson, R.B., and Granados, M.R. (2011). Evaluation of the VegSyst model with muskmelon to simulate crop growth, nitrogen uptake and evapotranspiration. Agric. Water Mgt. 101, 107-117. https://doi:10.1016/j.agwat.2011.09.008.

Gallardo, M., Thompson, B., and Fernández, M.D. (2013). Water requirements and irrigation management in Mediterranean greenhouses: the case of the southeast coast of Spain. In Good Agricultural Practices for Greenhouse Vegetable Crops. Principles for Mediterranean Climate Areas (Rome, Italy: FAO), p. 109-136.

Gallardo, M., Thompson, R.B., Giménez, C., Padilla, F.M., and Stöckle, C.O. (2014). Prototype decision support system based on the VegSyst simulation model to calculate crop $\mathrm{N}$ and water requirements for tomato under plastic cover. Irrig. Sci. 32, 237-253. https:// doi:10.1007/s00271-014-0427-3.

Gallardo, M., Fernández, M.D., Giménez, C., Padilla, F.M., and Thompson, R.B. (2016). Revised VegSyst model to calculate dry matter production, critical $\mathrm{N}$ uptake and $\mathrm{ET}_{\mathrm{c}}$ of several vegetable species grown in Mediterranean greenhouses. AGSY 146, 30-43. https://doi:10.1016/j.agsy.2016.03.014.

Gianquinto, G., Orsini, F., Fecondini, M., Mezzetti, M., Sambo, P., and Bona, S. (2011). A methodological approach for defining spectral indices for assessing tomato nitrogen status and yield. Eur. J. Agron. 35,135-143. https://doi.org/10.1016/j.eja.2011.05.005.

Glass, D.M. (2003). Nitrogen use efficiency of crop plants: physiological constraints upon nitrate absorption. Crit. Rev. Plant Sci. 22, 453-470. https://doi.org/10.1080/07352680390243512.

Goffart, J., Olivier, M., and Frankinet, M. (2008). Potato crop nitrogen status assessment to improve $\mathrm{N}$ fertilization management and efficiency: Past-Present-Future. Potato Res. 51, 355-383. https:// doi.org/10.1007/s11540-008-9118-x.

Granados, M.R., Thompson, R.B., Fernández, M.D., Martínez-Gaitán, C., and Gallardo, M. (2013). Prescriptive-corrective nitrogen and irrigation management of fertigated and drip-irrigated vegetable crops using modeling and monitoring approaches. Agric. Water Mgt. 119, 121-134. https://doi.org/10.1016/j.agwat.2012.12.014.

Grattan, S.R., Bowers, W., Dong, A., Snyder, R.L., Carroll, J.J., and George, W. (1998). New crop coefficients estimate water use of vegetables, row crops. Calif. Agric. 52, 16-21. https://doi. org/10.3733/ca.v052n01p16.

Hansen, B., Orloff, S., and Peters, D. (2000). Monitoring soil moisture helps refine irrigation management. Calif. Agric. 54, 38-42. https:// doi.org/10.3733/ca.v054n03p38.

Hartz, T.K. (2003). The assessment of soil and crop nutrient status in the development of efficient fertilizer recommendations. Acta Hortic. 627, 231-240. https://doi.org/10.17660/actahortic.2003.627.30.

Hartz, T.K. (2006). Vegetable production best management practices to minimize nutrient loss. HortTechnology 16, 398-403.

Hartz, T.K., and Hochmuth, G.J. (1996). Fertility management of dripirrigated vegetables. HortTechnology 6, 168-172.

Hartz, T.K., and Bottoms, G.B. (2009). Nitrogen requirements of dripirrigated processing tomatoes. Hortscience 44, 1988-1993.

Hochmuth, G.J. (1994). Efficiency ranges for nitrate-nitrogen and potassium for vegetable petiole sap quick tests. HortTechnology 4, 218-222.

Hochmuth, G.J. (2012). Plant petiole sap-testing for vegetable crops. http://edis.ifas.ufl.edu/pdffiles/CV/CV00400.pdf. 
Ibrahim, A., Wahb-Allah, M., Abdel-Razzak, H., and Alsadon, A. (2014). Growth, yield, quality and water use efficiency of grafted tomato plants grown in greenhouse under different irrigation levels. Life Sci. J. 11, 118-126.

Incrocci, L., Massa, D., and Pardossi, A. (2017). New trends in the fertigation management of irrigated vegetable crops. Horticulturae 3, 37. https://doi.org/10.3390/horticulturae3020037.

Kumar, P., Lucini, L., Rouphael, Y., Cardarelli, M., Kalunke, R.M., and Colla, G. (2015a). Insight into the role of grafting and arbuscular mycorrhiza on cadmium stress tolerance in tomato. Front. Plant Sci. 6, 477. https://doi.org/10.3389/fpls.2015.00477.

Kumar, P., Rouphael, Y., Cardarelli, M., and Colla, G. (2015b). Effect of nickel and grafting combination on yield, fruit quality, antioxidative enzyme activities, lipid peroxidation and mineral composition of tomato. J. Plant Nutr. Soil Sci. 6, 648-660. https://doi.org/10.1002/ jpln.201400651.

Kumar, P., Rouphael, Y., Cardarelli, M., and Colla, G. (2017). Vegetable grafting as a tool to improve drought resistance and water use efficiency. Front. Plant Sci. 8, 1130. https://doi.org/10.3389/ fpls.2017.01130.

Kyriacou, M.C., and Rouphael, Y. (2018). Towards a new definition of quality for fresh fruits and vegetables. Sci. Hort. 234, 463-469. https://doi.org/10.1016/j.scienta.2017.09.046.

Lemaire, G., Jeuffroy, M.H., and Gastal, F. (2008). Diagnosis tool for plant and crop $\mathrm{N}$ status in vegetative stage. Theory and practices for crop N management. Eur. J. Agron. 28, 614-624. https://doi. org/10.1016/j.eja.2008.01.005

Liu, S., Li, H., Lv, X., Ahammed, G.L., Xia, X., Zhou, J., et al. (2016) Grafting cucumber onto luffa improves drought tolerance by increasing ABA biosynthesis and sensitivity. Sci. Rep. 6, 1. https:// doi.org/10.1038/srep20212.

Locascio, S.J. (2005). Management of irrigation for vegetables: Past, present, and future. Horttechnology 15, 482-485.

López-Marin, J., Gálvez, A., del Amor, F.M., Albacete, A., Fernandez, J.A., Egea-Gilabert, C., et al. (2017). Selecting vegetative/generative/ dwarfing rootstocks for improving fruit yield and quality in water stressed sweet peppers. Sci. Hortic. 214, 9-17. https://doi. org/10.1016/j.scienta.2016.11.012.

Mannini, P., Genovesi, R., and Letterio, T. (2013). Large scale DSS application for on-farm irrigation scheduling. Procedia Environ. Sci. 19, 823-829. https://doi.org/10.1016/j.proenv.2013.06.091.

Martínez-Andújar, C., Ruiz-Lozano, J.M., Dodd, I.C., Albacete, A., and Pérez-Alfocea, F. (2017). Hormonal and nutritional features in contrasting rootstock-mediated tomato growth under lowphosphorus nutrition. Front. Plant Sci. 8, 533. https://doi. org/10.3389/fpls.2017.00533.

Meisinger, J.J., Schepers, J.S., and Raun, W.R. (2008). Crop nitrogen requirements and fertilization. In Nitrogen in Agricultural Systems (Madison, WI, USA: American Society of Agronomy), p. 563-612.

Migliaccio, K.W., Morgan, K.T., Vellidis, G., Zotarelli, L., Fraisse, C., Zurweller, B.A., Andreis, J.H., Grane, J.H., and Rowland, D.L. (2016) Smartphone apps for irrigation scheduling. Trans. ASABE 59, 291301. https://doi.org/10.13031/irrig.20152143940.

Munoz-Carpena, R., Dukes, M.D., Li, Y., and Klassen, W. (2008) Design and field evaluation of a new controller for soil-water based irrigation. Appl. Eng. Agric. 24, 183-191. https://doi. org/10.13031/2013.24266.

Munoz-Carpena, R., Dukes, M.D., Li, Y.C., and Klassen, W. (2005). Field comparison of tensiometer and granular matrix sensor automatic drip irrigation on tomato. Horttechnology 15, 584-590.
Olsen, J.K., and Lyons, D.J. (1994). Petiole sap nitrate is better than total nitrogen in dried leaf for indicating nitrogen status and yield responsiveness of capsicum in subtropical Australia. Aust. J. Exp. Agric. 34, 835-843. https://doi.org/10.1071/ea9940835.

Omirou, M., Ioannides, I.M., and Ehaliotis, C. (2013). Mycorrhizal inoculation affects arbuscular mycorrhizal diversity in watermelon roots, but leads to improved colonization and plant response under water stress only. Appl. Soil Ecol. 63, 112-119. https://doi. org/10.1016/j.apsoil.2012.09.013.

Orgaz, F., Fernández, M.D., Bonachela, S., Gallardo, M., and Fereres, E. (2005). Evapotranspiration of horticultural crops in an unheated plastic greenhouse. Agric. Water Mgt. 72, 81-96. https:// doi:10.1016/j.agwat.2004.09.010.

Padilla, F.M., Peña-Fleitas, T., Gallardo, M., and Thompson, R.B. (2014). Evaluation of optical sensor measurements of canopy reflectance and of leaf flavonols and chlorophyll contents to assess crop nitrogen status of muskmelon. Eur. J. Agron. 58, 39-52. https:// doi.org/10.1016/j.eja.2014.04.006.

Padilla, F.M., Peña-Fleitas, T., Gallardo, M., and Thompson, R.B. (2015). Threshold values of canopy reflectance indices and chlorophyll meter readings for optimal nitrogen nutrition of tomato. Ann. Appl. Biol. 166, 271-285. https://doi.org/10.1111/aab.12181.

Padilla, F.M., Peña-Fleitas, M.T., Gallardo, M., Giménez, C., and Thompson, R.B. (2017a). Derivation of sufficiency values of a chlorophyll meter to estimate cucumber nitrogen status and yield. Comput. Electron. Agr. 141, 54-64. https://doi.org/10.1016/j. compag.2017.07.005.

Padilla, F.M., Peña-Fleitas, M.T., Gallardo, M., and Thompson, R.B. (2017b). Determination of sufficiency values of canopy reflectance vegetation indices for maximum growth and yield of cucumber. Eur. J. Agron. 84, 1-15. https://doi.org/10.1016/j.eja.2016.12.007.

Pardossi, A., Incrocci, L., Incrocci, G., Malorgio, F., Battista, P., Bacci, L., Rapi, B., Marzialetti, P., Hemming, J., and Balendonck, J. (2009). Root zone sensors for irrigation management in intensive agriculture. Sensors 9, 2809-2835. https://doi.org/10.3390/s90402809.

Pardossi, A., and Incrocci, L. (2011). Traditional and new approaches to irrigation scheduling in vegetable crops. Horttechnology 21, 309311.

Parks, S.E., Irving, D.E., and Milham, P.J. (2012). A critical evaluation of on-farm rapid tests for measuring nitrate in leafy vegetables. Sci. Hortic. 134, 1-6. https://doi.org/10.1016/j.scienta.2011.10.015.

Parneaudeau, V., Jeuffroy, M.H., Machet, J.M., Reau, R., BissuelBelaygue, C., Eveillard, P., Ostergaard, H.S., and Orson, J.A. (2009). Methods for determining the nitrogen fertiliser requirements of some major arable crops. Proc. of the International Fertiliser Society, No. 661 (York, UK: International Fertiliser Society), p. 2-26.

Peña-Fleitas, T., Gallardo, M., Thompson, R.B., Farneselli, M., and Padilla, F.M. (2015). Assessing crop N status of fertigated vegetable crops using plant and soil monitoring techniques. Ann. Appl. Biol. 167, 387-405. https://doi.org/10.1111/aab.12235.

Regalado, C.M., Ritter, A., and García, O. (2010). Dielectric response of commercial capacitance, impedance and TDR electromagnetic sensors in standard liquid media. In Transactions of the Third International Symposium on Soil Water Measurement Using Capacitance, Impedance and TDT, Murcia, Spain, Paper 1.2.

Rhoades, J.D., and Loveday, J. (1990). Salinity in irrigated agriculture, In Irrigation of Agricultural Crops (Madison, USA: American Society of Agronomy), p. 1089-1142.

Rouphael, Y., and Colla, G. (2005). Radiation and water use efficiencies of greenhouse zucchini squash in relation to different climate parameters. Eur. J. Agron. 23, 183-194. https://doi.org/10.1016/j. eja.2004.10.003. 
Rouphael, Y., Cardarelli, M., Colla, G., and Rea, E. (2008). Yield, mineral composition, water relations, and water use efficiency of grafted mini-watermelon plants under deficit irrigation. HortScience 43, 730-736.

Rouphael, Y., Cardarelli, M., Di Mattia, E., Tullio, M., Rea, E., and Colla, G. (2010). Enhancement of alkalinity tolerance in two cucumber genotypes inoculated with an arbuscular mycorrhizal biofertilizer containing Glomus intraradices. Biol. Fertil. Soils 46, 499-509. https://doi.org/10.1007/s00374-010-0457-9.

Rouphael, Y., Cardarelli, M., Rea, E., and Colla, G. (2012). Improving melon and cucumber photosynthetic activity, mineral composition, and growth performance under salinity stress by grafting onto Cucurbita hybrid rootstocks. Photosynthetica 50, 180-188. https:// doi.org/10.1007/s11099-012-0002-1.

Rouphael, Y., Franken, P., Schneider, C., Schwarz, D., Giovanetti, M., Agnolucci, M., De Pascale, S.S., Bonini, P., and Colla, G. (2015). Arbuscular mycorrhizal fungi act as biostimulants in horticultural crops. Sci. Hortic. 196, 91-108. https://doi.org/10.1016/j. scienta.2015.09.002.

Rouphael, Y., Raimondi, G., Caputo, R., and De Pascale, S. (2016a). Fertigation strategies for improving water use efficiency and limiting nutrient loss in soilless Hippeastrum production. HortScience 51 684-689.

Rouphael, Y., Rea, E., Cardarelli, M., Bitterlich, M., Schwarz, D., and Colla, G. (2016b). Can adverse effects of acidity and aluminum toxicity be alleviated by appropriate rootstock selection in cucumber? Front. Plant Sci. 7, 1283. https://doi.org/10.3389/fpls.2016.01283.

Rouphael, Y., Colla, G., Giordano, M., El-Nakhel, C., Kyriacou, M.C., and De Pascale, S. (2017a). Foliar applications of a legumederived protein hydrolysate elicit dose dependent increases of growth, leaf mineral composition, yield and fruit quality in two greenhouse tomato cultivars. Sci. Hortic. 226, 353-360. https://doi. org/10.1016/j.scienta.2017.09.007.

Rouphael, Y., De Micco, V., Arena, C., Raimondi, G., Colla, G, and De Pascale, S. (2017b). Effect of Ecklonia maxima seaweed extract on yield, mineral composition, gas exchange, and leaf anatomy of zucchini squash grown under saline conditions. J. Appl. Phycol. 29, 459-470. https://doi.org/10.1007/s10811-016-0937-x.

Rouphael, Y., Colla, G., Graziani, G., Ritieni, A., Cardarelli, M., and De Pascale, S. (2017c). Phenolic composition, antioxidant activity and mineral profile in two seed-propagated artichoke cultivars as affected by microbial inoculants and planting time. Food Chem. 234, 10-19. https://doi.org/10.1016/j.foodchem.2017.04.175.

Rouphael, Y., Cardarelli, M., Bonini, P., and Colla, G. (2017d). Synergistic action of a microbial-based biostimulant and a plant derived-protein hydrolysate enhances lettuce tolerance to alkalinity and salinity. Front. Plant Sci. 8, 131. https://doi.org/10.3389/ fpls.2017.00131.

Rouphael, Y., Petropoulos, S.A., Cardarelli, M., and Colla, G. (2018a). Salinity as eustressor for enhancing quality of vegetables. Sci. Hortic. 234, 361-369. https://doi.org/10.1016/j.scienta.2018.02.048.

Rouphael, Y., Kyriacou, M.C., Petropoulos, S.A., De Pascale, S., and Colla, G. (2018b). Improving vegetable quality in controlled environments. Sci. Hortic. 234, 275-289. https://doi.org/10.1016/j. scienta.2018.02.033.

Rouphael, Y., Kyriacou, M.C., and Colla, G. (2018c). Vegetable grafting: A toolbox for securing yield stability under multiple stress conditions. Front. Plant Sci. 8, 2255. https://doi: 10.3389/fpls.2017.02255.

Samborski, S.M., Tremblay, N., and Fallon, E. (2009). Strategies to make use of plant sensor-based diagnostic information for nitrogen recommendations. Agron. J. 101, 800-816. https://doi.org/10.2134/ agronj2008.0162rx
Schröder, J.J., Neeteson, J.J., Oenema, O., and Struik, P.C. (2000). Does the crop or the soil indicate how to save nitrogen in maize production? Reviewing the state of the art. Field Crops Res. 66, 151164. https://doi.org/10.1016/s0378-4290(00)00121-0.

Shock, C.C., Pereira, A.B., Hanson, B.R., and Cahn, M.D. (2007). Vegetable irrigation. In Irrigation of Agricultural Crops (Madison, WI, USA: American Society of Agronomy), p. 535-606.

Slavin, J.L., and Lloyd, B. (2012). Health benefits of fruits and vegetables. Adv. Nutr. 3, 506-516.

Smith, M. (1992). CROPWAT. A computer program for irrigation planning and management, FAO Irrigation and Drainage Paper No. 46 (Rome, Italy: FAO Land and Water Development Division).

Sonneveld, C., and Voogt, V. (2009). Plant Nutrition of Greenhouse Crops (Dordrecht, The Netherlands: Springer), 431 pp.

Sonneveld, C., Van den Ende, J., and De Bes, S. (1990). Estimating the chemical composition of soil solutions by obtaining saturation extracts or specific 1:2 by volume extracts. Plant Soil 122, 169-175. https://doi.org/10.1007/bf02851971.

Soto, F., Gallardo, M., Thompson, R.B., Peña-Fleitas, T., and Padilla, F.M. (2015). Consideration of total available $\mathrm{N}$ supply reduces $\mathrm{N}$ fertilizer requirement and potential for nitrate leaching loss in tomato production. Agric. Eco. Environ. 20, 62-70. https://doi. org/10.1016/j.agee.2014.10.022.

Stirzaker, R.J., Stevens, J.B., Annandale, J.G., and Steyn, J.M. (2009) Stages in the adoption of a wetting front detector. Irrig. Drain. 59, 367-376. https://doi.org/10.1002/ird.472.

Thompson, R.B., and Gallardo, M. (2003). Use of soil sensors for irrigation scheduling. In Improvement of Water Use Efficiency in Protected Crops, M. Fernández Fernández, P. Lorenzo-Minguez, and M.I. Cuadrado López, eds. (Seville, Spain: Dirección General de Investigación y Formación Agraria de la Junta de Andalucía), p. 375402.

Thompson, R.B., Gallardo, M., Agüera, T., Valdez, L.C., and Fernández, M.D. (2006). Evaluation of the Watermark sensor for use with drip irrigated vegetable crops. Irrig. Sci. 24, 185-202. https://doi. org/10.1007/s00271-005-0009-5.

Thompson, R.B., Gallardo, M., Valdez, L.C., and Fernandez, M.D. (2007a). Using plant water status to define threshold values for irrigation management of vegetable crops using soil moisture sensors. Agric. Water Mgt. 88, 147-158. https://doi.org/10.1016/j. agwat.2006.10.007.

Thompson, R.B.B., Gallardo, M., Valdez, L.C.C., and Fernández, M.D. (2007b). Determination of lower limits for irrigation management using in situ assessments of apparent crop water uptake made with volumetric soil water content sensors. Agric. Water Mgt. 92, 13-28. https://doi.org/10.1016/j.agwat.2007.04.009.

Thompson, R.B., Gallardo, M., Fernandez, M.D., Valdez, L.C., and Martinez-Gaitan, C. (2007c). Salinity effects on soil moisture measurement made with a capacitance sensor. Soil Sci. Soc. Am. J. 71, 1647-1657. https://doi.org/10.2136/sssaj2006.0309.

Thompson, R.B., Martínez-Gaitán, C., Gallardo, M., Giménez, C., and Fernández, M.D. (2007d). Identification of irrigation and N management practices that contribute to nitrate leaching loss from an intensive vegetable production system by use of a comprehensive survey. Agric. Water Mgt. 89, 261-274. https://doi.org/10.1016/j. agwat.2007.01.013.

Thompson, R.B., Gallardo, M., Joya, M., Segovia, C., Martínez-Gaitán, C., and Granados, M.R. (2009). Evaluation of rapid analysis systems for on-farm nitrate analysis in vegetable cropping. Span. J. Agric. Res. 7, 200-211. https://doi.org/10.5424/sjar/2009071-412. 
Thompson, R.B., Gallardo, M., and Voogt, W. (2015). Optimizing nitrogen and water inputs for greenhouse vegetable production. Acta Hortic. 1107, 15-29. https://doi.org/10.17660/ actahortic.2015.1107.2.

Thompson, R.B., Tremblay, N., Fink, M., Gallardo, M., and Padilla, F.M. (2017a). Tools and strategies for sustainable nitrogen fertilisation of vegetable crops. In Advances in Research on Fertilization Management of Vegetable Crops, F. Tei, S. Nicola, and P. Benincasa, eds. (Cham, Switzerland: Springer), p. 11-63. https://doi. org/10.1007/978-3-319-53626-2_2.

Thompson, R.B., Incrocci, L., Voogt, W., Pardossi, A., and Magán, J.J. (2017b). Sustainable irrigation and nitrogen management of fertigated vegetable crops. Acta Hortic. 1150, 363-378. https://doi. org/10.17660/actahortic.2017.1150.52

Tognoni, F., La Malfa, G., Barbieri, G., Serra, G., Maggio, A., and Leonardi, C. (2002). Some aspects of the vegetable industry in Italy. Acta Hortic. 582, 121-133. https://doi.org/10.17660/actahortic.2002.582.10.

Vernieri, P., Borghesi, E., Tognoni, F., Serra, G., Ferrante, A., and Piagessi, A. (2006). Use of biostimulants for reducing nutrient solution concentration in floating system. Acta Hortic. 718, 477-484. https://doi.org/10.17660/ActaHortic.2006.718.55.

Voogt, W., Kipp, J.A., De Graaf, R., and Spaans, L. (2000). A fertigation model for glasshouse crops grown in soil. Acta Hortic. 537, 495-502. https://doi.org/10.17660/ActaHortic.2000.537.58.

$\mathrm{Xu}$, C., and Leskovar, D. (2015). Effects of A. nodosum seaweed extracts on spinach growth, physiology and nutrition valued under drought stress. Sci. Hortic. 183, 39-47. https://doi.org/10.1016/j. scienta.2014.12.004.

Ziegler, J., Strohmeier, K., and Brand, T. (1996). Nitrogen supply of vegetables based on the "KNS-system". Acta Hortic. 428, 223-234. https://doi.org/10.17660/actahortic.1996.428.23.

Received: Nov. 21, 2017

Accepted: May 15, 2018

Addresses of authors:

S. De Pascale ${ }^{1, *}$, Y. Rouphael $^{1, *}$, M. Gallardo ${ }^{2}$

and R.B. Thompson ${ }^{2}$

${ }^{1}$ Department of Agricultural Sciences, University of Naples

Federico II, Portici, Italy

${ }^{2}$ Department of Agronomy, CIAMBITAL Research Centre for

Mediterranean Intensive Agrosystems and Agrifood

Biotechnology, ceiA3 Agrifood Campus of International

Excellence, University of Almeria, Almeria, Spain

* Corresponding authors; E-mail: depascal@unina.it (S. De Pascale), youssef.rouphael@unina.it (Y. Rouphael) 